\title{
Fusiform Enlargement of the Superficial Temporal Artery in the Cases with Intracranial Aneurysm
}

\section{Intrakraniyal Anevrizmall Olgularda Süperfisiyal Temporal Arterin Füziform Genişlemesi}

\author{
Enis KURUOGLU, Cengiz COKLUK, Abdullah Hilmi MARANGOZ, Kerameddin AYDIN \\ Ondokuzmayıs University, School of Medicine, Department of Neurosurgery, Samsun, Turkey
}

Corresponding Author: Enis KURUOGLU / E-mail: drenis@hotmail.com

\begin{abstract}
AIM:The superficial temporal artery is one of the main terminal branches of the external carotid artery. This artery ascends through the lateralposterior margin of the zygomatic arch to reach the temporal region of the scalp. The superficial temporal artery divides its frontal and parietal branches around the zygomatic arch.

MATERIAL and METHODS: The raw data of the Three-dimensional Computerized Tomography Angiography (3D-CTA) were transferred to computer and recorded in a software program. This software program created the three-dimensional images of the superficial temporal artery using these transferred raw data with volume rendering technique.

RESULTS: Fifteen cases ( 5 female and 10 male, mean age $54.26 \pm 12.35$ years) with intracranial aneurysm were evaluated in terms of the type, location and dimensions of the fusiform enlargements. Fusiform enlargement was bilateral in eleven of the cases. Remaining four cases have unilateral fusiform enlargement of the superficial temporal artery.

CONCLUSION: Fusiform enlargement of the superficial temporal artery may be seen in the cases with intracranial aneurysms. 3D-CTA should be carefully evaluated in the demonstration of extracranial-intracranial vascular pathologies.
\end{abstract}

KEYWORDS: Fusiform enlargement, Intracranial aneurysm, Superficial temporal artery

öz

AMAÇ: Süperfisiyal temporal arter, eksternal karotis arterin ana terminal dallarından birisidir. Bu arter, zigomatik arkın lateral-posterior sınırından saçlı derinin temporal bölgesine boyunca uzanarak yukarı çıkar. Süperfisiyal temporal arter zigomatik ark çevresinde frontal ve paryetal dallara ayrılır.

YÖNTEM ve GEREÇLER: Üç boyutlu Bilgisayarlı Tomografi Anjiyografinin (3D-BTA) işlenmemiş verileri yazılım programına kaydedilerek bilgisayara transfer edildi. Bu işlenmemiş görüntülerden hacim oluşturma tekniği kullanılarak süperfisiyal temporal arterin üç boyutlu görüntüleri oluşturuldu.

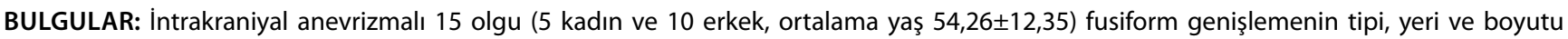
bakımından değerlendirildi. Füziform genişleme olguların 11'inde iki taraflıdı. Kalan 4 olguda süperfisiyal temporal arterin füziform genişlemesi tek taraflıydı.

SONUÇ: Süperfisiyal temporal arterin füziform genişlemesi intrakraniyal anevrizmalı olgularda gözlenebilir. 3D-BTA kraniyum içi ve dışı damarsal patolojilerin gösterilmesinde dikkatlice değerlendirilmelidir.

ANAHTAR SÖZCÜKLER: Füziform genişleme, İntrakraniyal anevrizma, Superfisiyal temporal arter

\section{INTRODUCTION}

Superficial temporal artery is one of the external carotid artery branches which has the duty of scalp feeding $(4,5)$. Facial artery, maxillary artery, occipital artery and posterior auricular artery are other arteries as they feed the scalp $(6,7)$. Superficial temporal artery was used as an anastomosis artery with distal branches of the middle cerebral artery during intracranial bypass surgery.

The volume rendering technique may be used in the threedimensional evaluation of some anatomical structures such as intracranial arterial aneurysms. Volume rendering technique is a group of modalities in the converting of two-dimensional images to the three-dimensional images $(1,3,8)$. The twodimensional images acquired by a computerized tomography and magnetic resonance imaging are used to create the volume rendered images $(1,2,3)$. In this study, we used OsiriX software program for volume rendering technique to create three-dimensional intracranial and extracranial arterial images.

The development of abnormal morphological pathologies such as aneurysm, fusiform dilatation, arteriovenous 
malformations is multifactorial in origin. The aneurysms are generally acquired degenerative lesions developing with the effect of hemodynamic stress. Connective tissue disorders and hypertension can be accepted as aggravating factors for the development of vascular abnormal pathologies. Some abnormal vascular pathologies including superficial temporal artery may be seen in some cases with degenerative or connective tissue disorders. The aneurysmatic dilatation of the superficial temporal artery may also be seen (9). Saccular, fusiform and pseudoaneurysmatic dilatations are the type of the aneurysms may be seen in this location (9). Such kind of pathologies may be presented with headache in the clinical practice. In the other hand, pterional craniotomy is commonly used for the surgical treatment of intracranial aneurysms. The morphologic structure of the superficial temporal artery should be taken into account during the surgical treatment of aneurysms.

In this report, fusiform enlargement of the superficial temporal artery in the cases with intracranial aneurysms was evaluated in terms of the location of the pathology, dimensions of the dilatations and the type of the intracranial pathology. The importance of three-dimensional computerized tomographic angiography (3D-CTA) with volume rendering technique was also emphasized in the diagnosing and classification of the pathology.

\section{MATERIAL and METHODS}

Any additional radiological examination and providing any drug were performed to the patients for this study. The patient population included the cases that were brought to our neurosurgery department because of subarachnoid hemorrhage, and further decided to perform a 3D-CTA for cerebral aneurysm evaluation. The raw data of the 3D-CTA were transferred and recorded to a computational software database. The purpose of performing 3D-CTA was only the examination of the intracranial vascular pathology after the insult of subarachnoid hemorrhage. Some part of these raw data were used for examination of the three dimensional anatomy of the superficial temporal artery. Any additional procedure was done any of the patients. Imaging data were stored in digital imaging and communications in medicine (DICOM) format and subsequent analyzed with imaging software to convert into the three-dimensional volume rendered neurovascular images. The computer program created the three-dimensional superficial temporal artery images using these transferred raw data with the volume rendering technique. Three-dimensional images of the superficial temporal artery were evaluated in terms of general shape, the presence of fusiform enlargement, the type, dimensions, and the location of the enlargement.

\section{RESULTS}

The total number consists of 15 ( 5 female and 10 male) patients. The mean age of the patients were estimated as $54.26 \pm 12.35$ years. Any additional radiological procedure and/or drug were performed to any patient for this study. The purpose of the radiological examination of the patients were only diagnosing and examining of their own disease. The radiological images from this examination were retrospectively transferred to a computer. The Three Dimensional superficial temporal artery images were created with 3D-Volume Rendering Technique by using OsiriX MD software program (Figure 1). Threedimensional volume rendered anatomy of the superficial temporal artery was shown in Figure 1.

Unilateral fusiform enlargement of the superficial temporal artery was present in four $(26.66 \%)$ cases. In the remaining $11(73.34 \%)$ cases, the fusiform enlargement of the artery was bilateral. The type of the enlargement was divided into three main groups as bifurcational, segmental, and focal (Figure 2). Three main groups of fusiform enlargement were schematically shown in Figure 1. The bifurcational fusiform enlargement of the superficial temporal artery was found in two $(13.33 \%)$ of the cases (Figure 3). The focal enlargement was present in $5(33.33 \%)$ cases (Figure 4$)$. In the remaining $8(53.34 \%)$ of the cases, the enlargement of the superficial temporal artery was segmental (Figure 5). In this group, segmental and bifurcational enlargement was mainly bilateral.

The location of the intracranial aneurysm was also evaluated using three-dimensional volume rendered technique. Three (20\%) of the cases had posterior communicating aneurysm on the left side. The intracranial aneurysm was located on the left middle cerebral artery in four (26.66\%) of the cases. Right middle cerebral artery was affected in four $(26.66 \%)$ of the cases. In the remaining four (26.68\%) of the cases, the location of the intracranial aneurysm was anterior communicating artery.

The dimension of the fusiform enlargement was estimated using the estimation tool of the computer software. The minimal enlargement was found as 0.32 centimeter in diameter. In the other hand the maximal enlargement was

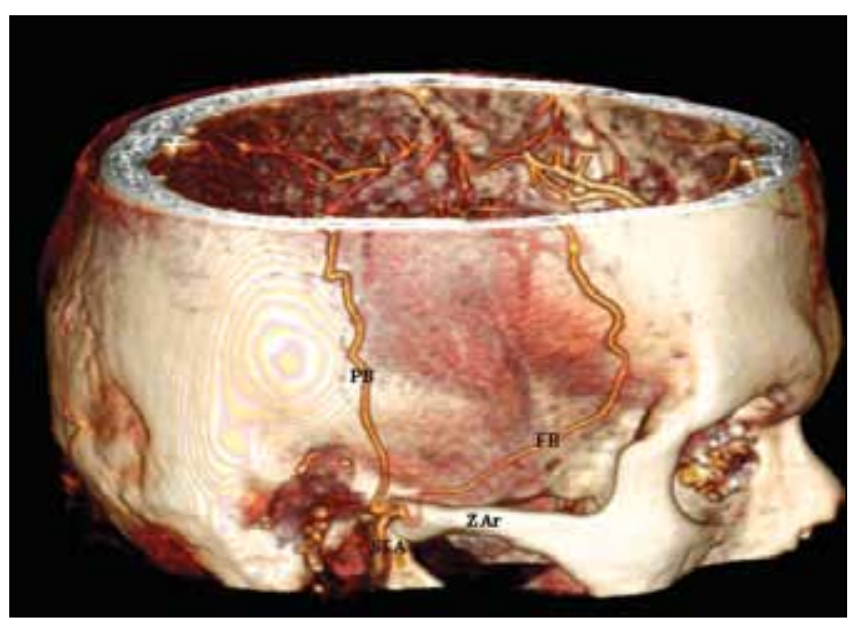

Figure 1: Three-dimensional volume rendered anatomy of the superficial temporal artery was shown in this figure (STA: superficial temporal artery; ZAr: zygomatic arc; FB: frontal branch; PB: parietal branch). 
found as 0.99 centimeter in diameter. The median diameter of the enlargement of the superficial temporal artery was estimated as $0.48 \pm 0.16$ centimeter in the patients (Table I).

\section{DISCUSSION}

The superficial temporal artery is one of the external carotid artery branches mainly feeding the scalp $(4,5)$. The other branches of the external carotid artery are the facial artery, maxillary artery, occipital artery, and the posterior auricular artery. The superficial temporal artery divides into frontal and parietal branches after emerging from the external carotid

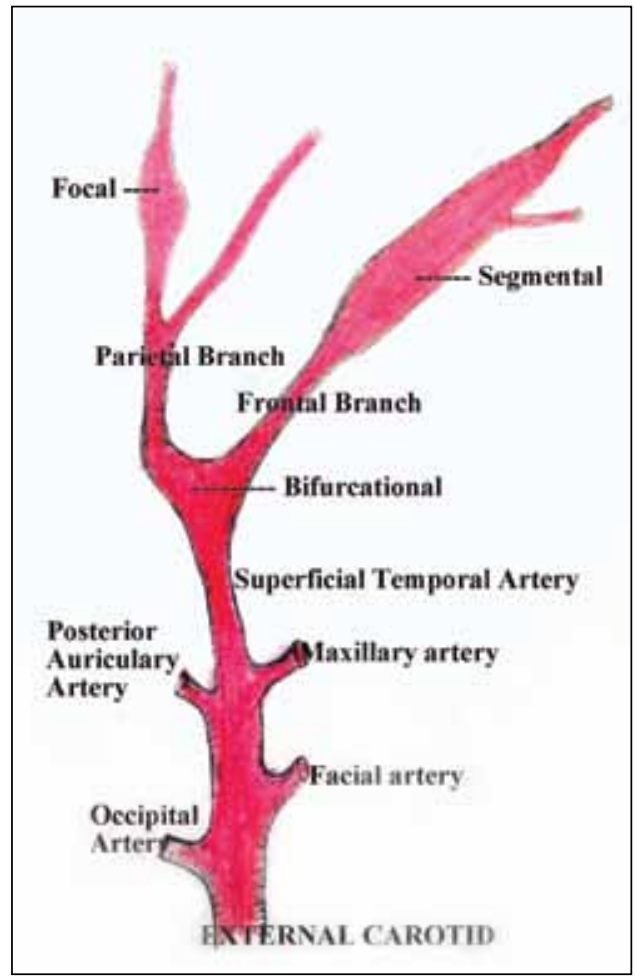

Figure 2:

Three main groups of fusiform enlargement were schematically shown in this figure.

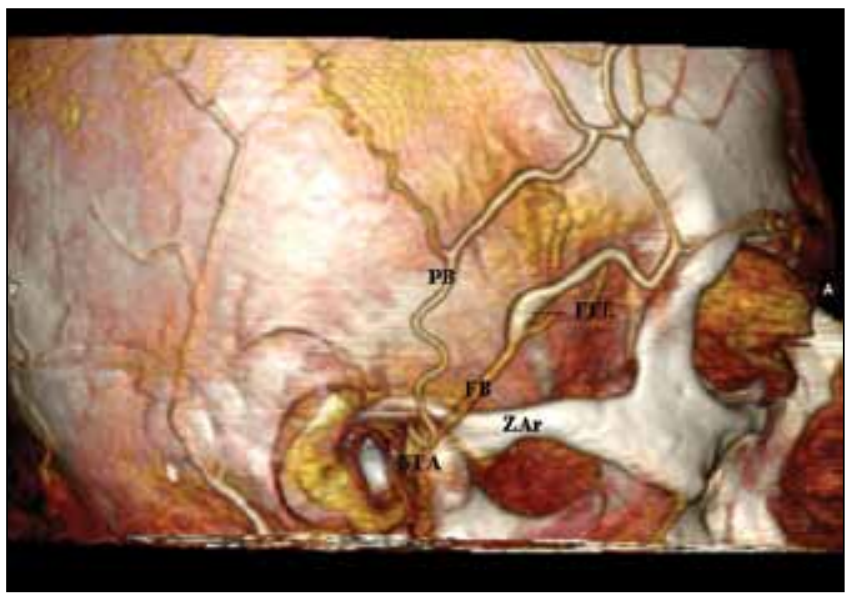

Figure 4: The focal fusiform enlargement of the superficial temporal artery is shown in this figure (STA: superficial temporal artery; ZAr: zygomatic arc; FB: frontal branch; PB: parietal branch; FFE: focal fusiform enlargement). artery in front of the tragus $(6,7)$. The course of the superficial temporal artery can be followed across the posterior end of the zygomatic arch. The pulsation of the superficial temporal artery with its branches (frontal and parietal) may be detected by finger. In some cases, the pulsation of the frontal branch may also visible at the frontal region.

Pterional craniotomy is commonly used in the surgery for cranial base and basal cerebral arteries. Standard curvilinear pterional skin incision is used for pterional craniotomy. In the performing of standard pterional skin incision, the point

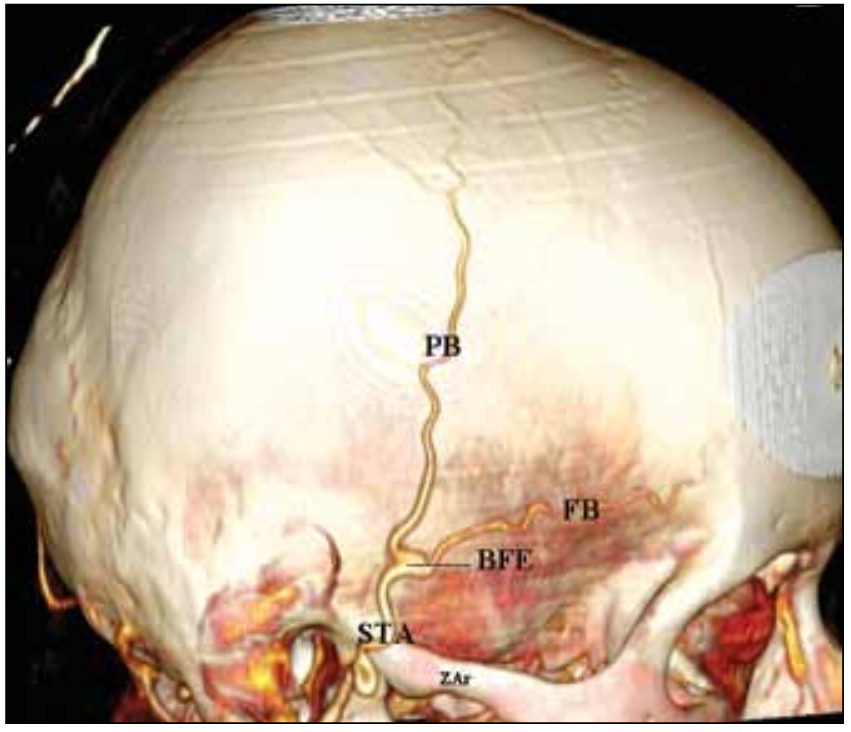

Figure 3: The bifurcational fusiform enlargement of the superficial temporal artery is shown in this figure (STA: superficial temporal artery; ZAr: zygomatic arc; FB: frontal branch; PB: parietal branch; BFE: bifurcational fusiform enlargement).

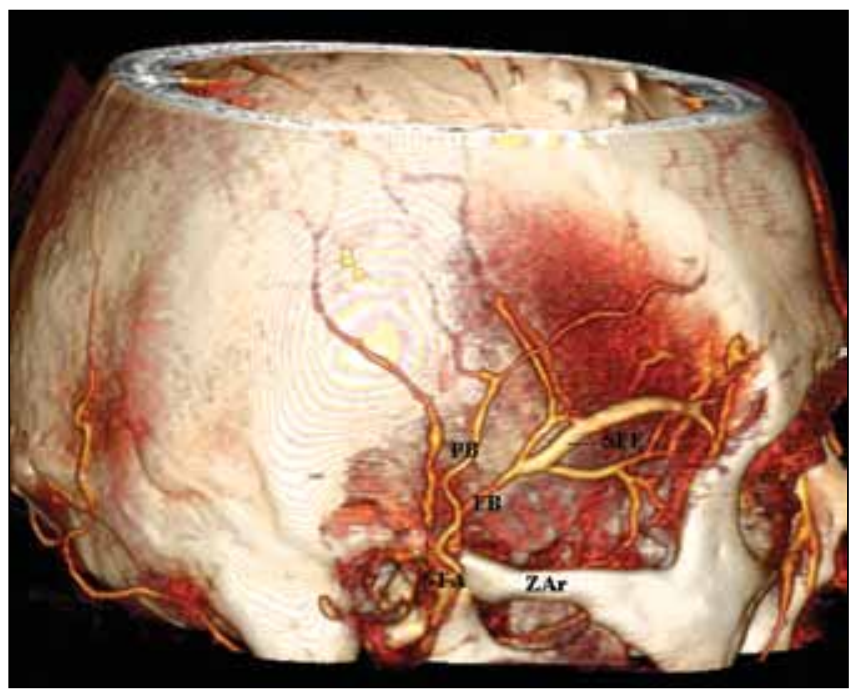

Figure 5: The segmental fusiform enlargement of the superficial temporal artery is shown in this figure (STA: superficial temporal artery; ZAr: zygomatic arc; FB: frontal branch; PB: parietal branch; SFE: focal fusiform enlargement). 
Table I: The Side and the Type of the Fusiform Enlargement of the Superficial Temporal Artery, the Location of the Intracranial Arterial Aneurysm, and the Diameter of the Fusiform Enlargement are Detailed in the Table

\begin{tabular}{|c|c|c|c|c|c|c|}
\hline No & $\begin{array}{c}\text { Age } \\
\text { (years) }\end{array}$ & $\operatorname{Sex}$ & $\begin{array}{c}\text { Side of } \\
\text { Enlargement }\end{array}$ & $\begin{array}{c}\text { Type of } \\
\text { Enlargement }\end{array}$ & Location of Intracranial Aneurysm & $\begin{array}{l}\text { Diameter of Fusiform } \\
\text { Enlargement (cm) }\end{array}$ \\
\hline 1 & 56 & $\mathrm{~F}$ & Bilateral & Bifurcational & Left Posterior Communicating Artery & 0.67 \\
\hline 2 & 83 & $\mathrm{~F}$ & Unilateral & Segmental & Left Posterior Communicating Artery & 0.32 \\
\hline 3 & 46 & $\mathrm{~F}$ & Bilateral & Focal & Left Posterior Communicating Artery & 0.54 \\
\hline 4 & 57 & $\mathrm{~F}$ & Bilateral & Segmental & Left Middle Cerebral Artery & 0.99 \\
\hline 5 & 41 & M & Bilateral & Segmental & Left Middle Cerebral Artery & 0.39 \\
\hline 6 & 43 & M & Bilateral & Segmental & Left Middle Cerebral Artery & 0.42 \\
\hline 7 & 56 & M & Unilateral & Focal & Left Middle Cerebral Artery & 0.35 \\
\hline 8 & 51 & M & Bilateral & Segmental & Right Middle Cerebral Artery & 0.39 \\
\hline 9 & 55 & M & Bilateral & Segmental & Right Middle Cerebral Artery & 0.48 \\
\hline 10 & 67 & M & Bilateral & Segmental & Right Middle Cerebral Artery & 0.41 \\
\hline 11 & 37 & M & Unilateral & Focal & Right Middle Cerebral Artery & 0.41 \\
\hline 12 & 60 & $\mathrm{~F}$ & Bilateral & Bifurcational & Anterior Communicating Artery & 0.59 \\
\hline 13 & 74 & M & Bilateral & Focal & Anterior Communicating Artery & 0.39 \\
\hline 14 & 45 & M & Unilateral & Focal & Anterior Communicating Artery & 0.49 \\
\hline 15 & 45 & M & Bilateral & Segmental & Anterior Communicating Artery & 0.49 \\
\hline \multicolumn{6}{|c|}{ Mean \pm Standard Deviation } & $0.48 \pm 0.16$ \\
\hline
\end{tabular}

M: Male, F: Female.

of 1 or 1.5 centimeter in front of the tragus and the crossing point at the hairy scalp and perpendicular line drawn from the ipsilateral midpupil are the ending and starting point of the skin incision respectively. The curvilinear line drawing between these two points staying inside the hairy skin is described as standard pterional skin incision.

It is recommended the protection and dissection of superficial temporal artery as much as possible in the performing of pterional skin incision for pterional craniotomy. The superficial temporal artery is used as an anastomosis artery in the intracranial-extracranial by-pass surgery.

In this study, the fusiform enlargement of the superficial temporal artery of 15 cases associated with intracranial aneurysm was evaluated in terms of the description of the abnormality. The side of enlargement was evaluated in the determination of the laterality. The fusiform enlargement was bilateral in $73.34 \%$ of the cases. The unilateral fusiform dilatation of the artery was present in $26.66 \%$ of the cases. This data revealed that the ratio of bilateral enlargement of the superficial temporal artery is higher than those of the ratio of unilateral enlargement.

The type of the enlargement was divided into three groups as bifurcational, segmental, and focal. The bifurcational fusiform enlargement of the superficial temporal artery was found in $13.33 \%$ of the cases. The focal enlargement was present in $33.33 \%$ cases. In the remaining $53.34 \%$ of the cases, the enlargement of the superficial temporal artery was segmental. The data of the present study revealed that the fusiform enlargement of the superficial temporal artery is mainly segmental pathology. $20 \%$ of the cases had posterior communicating artery aneurysm on the left side. The intracranial aneurysm was located on the left middle cerebral artery in $26.66 \%$ of the cases. Right middle cerebral artery was affected in $26.66 \%$ of the cases. In the remaining $26.68 \%$ of the cases, the location of the intracranial aneurysm was anterior communicating artery. The result of this study revealed that there is no aneurysmal predominance in terms of the location of the intracranial aneurysm. The minimal enlargement was found as 0.32 centimeter in diameter. In the other hand the maximal enlargement was found as 0.99 centimeter in diameter. The median diameter of the enlargement of the superficial temporal artery was estimated as $0.48 \pm 0.16$ centimeter in the patients.

\section{CONCLUSION}

The fusiform enlargement of the superficial temporal artery can be seen in the cases with intracranial aneurysms. The superficial temporal artery can be used as the by-pass artery for intracranial-extracranial blood diversion procedures in the neurosurgical procedures. The type, shape and location of the artery can be visualized and evaluated by using threedimensional volume rendering technique. 


\section{REFERENCES}

1. Calboun PS, Kuszyk BS, Heath DG, Carley JC, Fishman EK: Three-dimensional volume rendering of spiral CT data: Theory and method. RadioGraphics 19(3): 745-763, 1999

2. Drebin RA, Carpenter L, Hanrahan P: Volume rendering. Comput Graph 22: 65-74, 1988

3. Hwang SB, Kwak HS, Han YM, Chung GH: Detection of intracranial aneurysms using three dimensional multidetector-row CT angiography: Is bone subtraction necessary? European Journal of Radiology 79: e18-e23, 2011

4. Kim BS, Jung YJ, Chang CH, Choi BY: The anatomy of the superficial temporal artery in adult Koreans using 3-Dimensional computed tomographic angiogram: Clinical research. Journal of Cerebrovascular and Endovascular Neurosurgery 15(3):145-151, 2013
5. Mwachaka P, Sinkeet S, Ogeng'o J: Superficial temporal artery among Kenyans': Pattern of branching and its relation to pericranial structures. Folia Morphol (Warsz) 69: 51-53, 2010

6. Pınar YA, Govsa F: Anatomy of the superficial temporal artery and its branches: Its importance for surgery. Surg Radiol Anat 28: 248-253, 2006

7. Tayfur V, Edizer M, Magden O: Anatomic bases of superficial temporal artery and temporal branch of fasial nerve. J Craniofac Surg 21: 1945-1947, 2010

8. Tomandi BF, Hammen T, Klotz E, Ditt H, Stemper B, Lell M: Bone-substraction $C T$ angiography for the evaluation of intracranial aneurysms. AJNR Am J Neuroradiol 27:55-59, 2006

9. Walker MT, Liu BP, Salehi SA, Badve S, Batjer HH: Superficial temporal artery pseudoaneurysm: Diagnosis and preoperative planning with CT angiography. AJNR Am J Neuroradiol 24: 147-150, 2003 